\title{
Чепинога А.В. Режиссерская интерпритация авторского замысла в драматическом и оперном спектакле
}

\begin{abstract}
Аннотация: Предметом исследования в данной статье является механизм интерпретации авторского материала в работе режиссера. При этом особое внимание уделяется точному разграничению понятий «искусство» и «жизнь», указываются принципиальные отличия одного от другого, высказывается мысль о недопустимости «копиизма» на сцене. Показывается, что «искусство» - это особым образом «смонтированный объект», в основе структуры которого заложен ряд упорядоченных понятий, складывающихся в единство идеи. Особо подчеркивается, что идея есть организующий, структурный принцип искусственного объекта, а так же подробно показано, каким образом, способом, какими средствами «жизненный объект» превращается в «искусственный». Особо подчеркивается, что авторский замысел есть «первый уровенъ» интерпретации жизни, а режиссерский - «второй уровенъ» интерпретации жизни. В статье проведён тщательный теоретический анализ, который позволяет выделить отдельные стороны, признаки, особенности, свойства и принци действия механизма интерпретации. Кроме того, на тему исследования проведено тщательное изучение специальной литературы по теории драматической и оперной режиссуры (малая часть из которого представлена в списке литературы) с подробным конспектированием и цитированием. Тщательное изучение значительного корпуса теоретической литературы классиков теории действенного анализа пьесы, а так же материалов современной периодической печати позволяет установить, что за последние тридиать лет в области теоретического режиссерского знания не сделано ничего существенного. В научный обиход не введено ни одного нового или уточняющего конкретного понятия действенного анализа пьесы или партитуры. В частности, принципиально не описан и не раскрыт сам механизм режиссерской интерпретации авторского драматургического материала, способ его функционирования при постановке спектакля. Что порождает огромное количество весъма произвольных толкований его в режиссерской практике и приводит не только к искажению исходного авторского замысла драматурги или композитора, но и позволяет режиссерам создавать свои произведения с весьма существенными искажениями исходного материала, а так же - использовать пьесу или партитуру автора только как повод для собственной, весьма произвольной, «авангардистской», т.е. ничем не ограниченной фантазии.
\end{abstract}

Ключевые слова: Театр, режиссура, теория режиссуры, действие, действенный анализ, опера, оперная режиссура, интерпретация, авангардизм, структура.

Review: The subject of the research is the interpretation of the mechanism for interpreting the author's content in directing. Particular attention is paid to the exact distinction between "art" and "life". The author specifies the fundamental differences between these two concepts and expressed the idea of inadmissibility of "copyism" on stage. It is shown that "art" is a special type of "the mounted object" that is based on a number of concepts emerging in the unity of ideas. It is emphasized that idea is the organizing structural principle of an artificial object, the author also shows in detail how and by what means a 'physical object' turns into 'artificial'. It is emphasized that the author's intent is the "first-level" interpretation of life, and directing is the "second-level" interpretation of life. The article provides a thorough theoretical analysis, which allows to highlight certain aspects, features, aspects and operations of the mechanism of interpretation. In addition, the author studies examines literature on the theory of drama and opera directing (a small part of which is shown in the list of references) with a detailed note-taking and citation. Analysis of a large body of classical theoretical literature on the theory of the active analysis of the play, as well as modern materials of the periodical press allows to establish that over the past thirty years nothing substantial has been done in the sphere of directing theory. The academic community has not created any new concepts, neither has it clarified a specific active analysis of the play or director's script. In particular, the mechanism of the director's interpretation of the author's dramatic material, the way of its functioning in the production of the play have never been fully described or revealed. This gives rise to a huge number of 
loose interpretations in directing practice and leads not only to the distortion of the original intent of a playwright or composer, but also allows the filmmakers create their works with a very significant distortions of the raw material, as well as to use the play or director's script only as a pretext for their own, very arbitrary, "avant-garde", i.e. unfettered imagination.

Keywords: Interpretation, directing of opera, opera, active analysis, action, theory of directing, directing, theatre, avant-garde, structure.

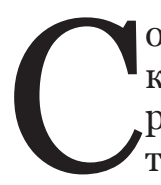
о времен благословенного Пролеткульта, театральная программа которого провозгласила, что цель ее работы «не в «использовании ценностей прошлого» или «изобретении новых форм театра», а в упразднении самого института театра как такового с заменой его показательной станцией достижений в плане поднятия квалификации бытовой оборудованности масс» [17, с. 269] в режиссерской практике прочно поселилось стойкое заблуждение: постановка, следующая за автором, исследовавшая его изначальный замысел, не является «передовой» и «авангардной». В борьбе со слащавой иллюстративностью и псевдо-жизнеподобием, которым в массе своей отличался театр предреволюционного времени (впрочем, как и современный!), как всегда от излишнего старания с купелью выплеснули и ребенка, прочно встав на «Путь, совершенно высвобождающий театр из-под гнета до сих пор решающей, неизбежной и единственно возможной «иллюзорной изобразительности» и «представляемости»» [17, с. 269]. Превратно понятое положение С.М. Эйзенштейна о том, что «не раскрытие замысла драматурга, правильное истолкование автора, «верное отображение эпохи» и т.п., а только аттракционы и система их являются единственной основой действенности спектакля» [17, с. 269] к сожалению, стало подлинным лозунгом любого «прогрессивного» начинания в театре. И одновременно действенным оправданием любого, кто сегодня, не слишком утруждая себя знанием в области теории режиссуры, берется поразить зрителя очередным «авангардным» откровением. Самоцельная погоня за «монтажом аттракционов» породила особую режиссуру, которая решила «не связывая себя логически бытовым и литературно-традиционным пиететом, установить данный подход как постановочный метод...» [17, с. 270].

Между тем, есть все основания думать, что С.М. Эйзенштейн был действительно несколько превратно понят, а его гениальная теория была демагогически использована как прикрытие неумения поставить спектакль. Так ка- жется уже потому, что его собственные спектакли и кинокартины не отличались той бессвязностью и бессмысленностью «монтажа» эффектов ради эффектов, которыми сегодня славятся постановки супер-продвинутых молодых режиссеров. Как, впрочем, не грешили собственные работы С.М. Эйзенштена бьющим по глазам копиизмом жизни, который сегодня тоже выдается за самое современное веяние времени. Напротив, как раз режиссура самого С.М. Эзенштейна - это то самое пресловутое «идеальное раскрытие замысла драматурга», «правильное его истолкования» и «верное отображения эпохи». Кроме того, он и сам указывал на опасность демагогического использования найденных им принципов режиссуры: «авторы ряда фильмов последних лет настолько начисто «разделались» с монтажом, что забыли даже основную его цель и задачу, неотрывную от познавательной роли, которую ставит себе всякое произведение искусства, - задачу связно последовательного изложения темы, сюжета, действия, поступков, движения внутри киноэпизода и внутри кинодрамы в целом». [17, с. 270]

Каким же образом тогда «авангардизм» сочетается с «верным истолкованием автора» (и может ли он вообще «сочетаться»?) и что на самом деле есть интерпретация литературной (музыкальной) основы, предложенной автором для работы режиссера?

В вопросах интерпретации художественного произведения, как, впрочем, во всей теории режиссуры, коренится множество неясностей. Даже наиболее верные из определений грешат расплывчатостью, не выявляя рабочего механизма интерпретации и потому допуская «зазор», позволяющий демагогически использовать эти положения. Общеизвестно, что «...в искусстве жизнь не отражается зеркально, т.е. в том виде, как она непосредственно воспринимается нашими органами чувств. Пройдя через сознание художника, она дается нам в познанном и преображенном виде, вместе с мыслями и чувствами художника, которые были вызваны явлениями жизни. Художественное воспроизведение впитывает, 
вбирает в себя мысли и чувства художника, выражающие его отношение к изображаемому предмету, и это отношение преобразует предмет, превращая его из феномена жизни в феномен искусства - в художественный образ. Правдиво показать каждое явление жизни в его сущности, раскрыть важную для жизни людей истину и заразить их своим отношением к изображаемому, своими чувствами - в этом задача художника. Если этого нет, и все достоинства произведения ограничиваются элементарным внешним правдоподобием, то ценность произведения оказывается ничтожной»[1, с. 227]. Эмоциональность высказывания, при всей своей правильности, совершенно не раскрывает таких ключевых понятий, как «произведение искусств», и уж тем более не демонстрирует механизма, каким образом произведение искусства «вбирает в себя мысли и чувства художника»? Из этого высказывания, как и из многих других ему подобных совершенно не ясно, что значит «раскрыть важную для жизни люде истину»? И почему так плохо «внешнее правдоподобие»?

Для исследования механизма интерпретации, видимо, следует выяснить, а зачем в театре нужен автор? И каким образом вообще автор создает пьесу или композитор - партитуру? И уж тогда понять, что такое интерпретация авторского замысла в работе режиссера.

Читая классиков, слушая музыку, становится совершенно понятно, что никто из них, создавая свои произведения, в точности не скопировал изложенные в них события из жизни. В каждом волей фантазии автора допущены зачем-то существенные искажения и в месте, и в ходе событий, и в характерах персонажей (иногда один персонаж формируется из суммы реальных лиц, например!) и т. д. В этом случае мы уверенно говорим о праве художника на фантазию, на создание собственной искусственной, художественной реальности и... на этом останавливаемся, совершенно не отдавая себе отчета в том, зачем это нужно. Между тем, именно это и отличает произведение искусства от жизненной реальности, делая невозможной снимание с этой реальности «дословной» копии. В противном случае, единственное, что оставалось бы автору (художнику) - особенно при современномто уровне техники! - это включить видеокамеру, которая стала бы фиксировать каждый шаг живущего человека и наладить on-line трансляцию (частично эту роль сегодня выполняют бесконечные жвачки-сериалы, шоу, стилистика театра .doc а то и просто реальные on-line трансляции, выдаваемые за театральный спектакль).

Однако, в этом случае разумен вопрос: а зачем зритель, проживающий свою собственную жизнь, озабоченный собственными проблемами, должен наблюдать за тем, как такой же человек, как и он, просыпается утром, ходит на работу, жует котлету или ухаживает за женщиной, словом, по выражению гениального А.П. Чехова «есть, пьет, носит свои пиджаки...» ${ }^{\text {? }}$ Какое-то время зритель, конечно, потратит на рассматривание иной, чем у него, например, формы зубной щетки или полюбуется женщиной, которая красивее, чем его собственная жена. И далее? Далее ему просто наскучит «подглядывать в щелочку» и он займется своими делами. Не может же он потратить всю свою жизнь на созерцание чужой жизни, особенно, когда она развивается в оnline режиме, т.е. в том реальном времени, которое зритель сам затрачивает на проживание собственной жизни. Даже в античные времена и во времена Шекспира, когда спектакли были несоизмеримо длиннее, чем сейчас, занимая целый день, они все же заканчивались, как заканчиваются, слава богу, когда-нибудь и самые длинные сериалы.

Значит, коренное отличие произведения искусства от реальной жизни уже хотя бы в том, что последнее существенно, по сравнению с реальной жизнью, ограницено во времени (что само по себе уже есть искажение реальности и отрицает сценический копиизм). Благодаря этому «сжатию», реально проходившие в два-три года события в авторском «прочтении» могут уложиться, например, в два-три дня или в месяц. За счет этого из реального временного отрезка жизни и фактов, которые имели место быть за этот отрезок, получается как бы квинтэссенция, предельно насыщенный раствор. А главное, даже если автор предпочитает следовать за реальным ходом времени и растягивает время действия на те же самые несколько лет, то, во-первых, он все равно будет вынужден прибегнуть к определенному отбору и «монтажу», чтобы уложиться в отведенные на театральное представление два-три традиционных часа. А во-вторых, в связи с применением этого самого отбора и «монтажа», он все равно пренебрегает огромным количеством других фактов, заполнявших жизнь героев все эти годы, и въбирает из каждого года лишь те узловые моменты, которые 
зачем-то кажутся ему наиболее яркими. То есть произведение искусства (пьеса, партитура) зачем-то показывает зрителю некую квинтэссенцию жизни героев, искусственно «стянутую» в ограниченные временные рамки, а не сам естественный жизненный ход. C.M. Эйзенштейн особо подчеркивал, что это свойство характерно не только для кино: «монтажное мышление и монтажные принципы широко представлены во всех видах искусства, смежных с литературой: в театре, в кино, в фотомонтаже и т.д.» $[17$, с. 269] Именно так рождается роман, рассказ, пьеса и оперная партитура (совершенно так же - картина, скульптура и пр.) ${ }^{2}$. И любой из этих «искусственных» объектов организован по принципу сжатия времени, отбора фактов и их смыслового обобщения, то есть того, что великий C.M. Эйзенштейн совершенно справедливо назвал «монтажом аттракционов»: «Настоящий подход коренным образом меняет возможности в принципах конструкции «воздействующего построения» (спектакль в целом): вместо статического «отражения» данного, по теме потребного события и возможности его разрешения единственно через воздействия, логически с таким событием сопряженные, выдвигается новый прием - свободный монтаж произвольно выбранных, самостоятельных (также и вне данной композиции и сюжетной сценки действующих) воздействий (аттракционов), но с точной установкой на определенный конечный тематический эффект - монтаж аттракционов» [17, с. 269].

Ограничение во времени и «перемонтирование», «спрессовывание» реальных событий есть первые два и главные признаки искусственности, а значит - искусства. Именно они отличают жизнь от ее сценической копии. А поскольку это так, то разумен следующий вопрос: какие же из всего потока фактов, составляющих каждодневную человеческую жизнь, должны войти в те сакраментальные два-три часа, которые сегодня длится оперный или драматический спектакль, а какими можно пренебречь?

И тут автор любого художественного произведения (будь то пьеса, партитура оперы или скульптура) становится не только перед проблемой выбора этих самых определенных моментов жизни своих героев, которые надо «втиснуть» в определенный отрезок времени, но и должен серьезно озаботиться критерue⿻ их отбора. И наличие такого критерия есть третий важный признак отличия произведения искусства от реальной жизни.

Каким же образом находится этот критерий? Берется ли он «с потолка» (т. е. выдумывается от себя и «встраивается» в произведение, как это делается зачастую сегодня) или же он каким-то образом «заложен» в избираемых для написания произведения событиях?

Реальная человеческая жизнь развивается естественным ходом, каждодневным течением сменяющих друг друга фактов, которые возникают в хаотическом, бессистемном и кажущемся необъяснимым, случайном порядке. Поэтому естественная человеческая жизнь в информационном плане может рассматриваться (и зачастую так и рассматривается ${ }^{3}$, как аморфная среда, не несущая собой никакого смысла.

Но, однако, если остановить свое внимание на определенном участке такой жизни (или на целой жизни - например, чьей-то биографии) и задаться целью понять, а почему именно такие, а не какие-нибудь иные события происходили в жизни этого человека, то мы неминуемо будем искать нечто объединяюuцее эти события, т.е.прuчนны их породившие. И обнаружим, что всю выбранную нами человеческую биографию, при разнообразии фактов и событий, ее составляющих, пронизывает некое единство прищин ${ }^{4}$. Так нам станет очевидна определенная идея биографии: скажем, выяснится, что все «приключения» этой биографии определились личным феноменальным человеческим упрямством, или, напротив, излишней покладистостью и. т.д. При пересказе этой биографии другому человеку, мы будем излагать уже не только и не столько цепочку фактов, но акцентировать внимание слушателя именно на этих причинах, показывая, что если бы, например, не упрямство героя нашего рассказа, или не его излишняя покладистость, то события явно повернулись бы по другому.

Но - «что он Гекубе, что ему Гекуба?»5 Зачем нужны эти причины, зачем же нужна эта идея, воспринимающему рассказ субъекту? Не все ли равно, упрям был герой или покладист - что нам до его жизни?

Здесь мы неумолимо вторгаемся в законы человеческого общения, главный из которых гласит, что человек будет интересен подобному себе только в том случае, если предоставляет свежую, новую и актуальную информацию. Что в свою очередь ставит вопрос о том, что такое информация и что ею 
является? Будет ли актуальной информацией считаться предъявленный голый факт или для воспринимающего субъекта важнее будет его оценка? Иначе говоря, чем обмениваются люди в общении: сенсациями или уникальным опытом?

Как известно, у человека всего два базовых инстинкта: выживания и продолжения жизни. И среди прочего разнообразия интересующих человека вещей все, что касается способов выживания и возможностей продолжения собственной жизни будет наиболее актуальным, поскольку вопрос о возможной смерти индивида, думает он об этом или нет, подсознательно преследуют его все время его биологического существования. Инстинкт выживания, «прошитый» как в компьютере, в саму природу человека будет заставлять личность всегда прежде всего интересоваться информацией, которая помогает ему адаптироваться в социуме, выстроить гармоничные отношения с себе подобными, прокормить и вырастить детей, приспособиться к окружающей его природной среде (все это инстинкт продолжения жизни), а инстинкт самосохранения будет требовать информации, как, какими способами гарантировано избежать одиночества, насилия и физического уничтожения (т. е. смерти). Соответственно, личность на пути выживания всегда в приоритете будет интересоваться именно этим опытом, заимствуя наиболее актуальные приемы продолжения жизни и выживания у других людей. И избегая причин, вызывающих болезни, одиночество и смерть. Человеку всегда будет интересны именно те приемы, которые позволят индивидууму при минимальной затрате сил на выживание в бесконечно меняющихся условиях жизни наиболее полно осуществить это выживание. Именно это и является наиболее актуальной информацией.

Но вряд ли голый случившийся факт является носителем этого опыта. Он скорее отражает, выявляет последствия его применения. Личность же всегда будут интересовать причины, почему этот факт случился. Именно они и будут тем самым актуальным опытом, той самой «свежей» информацией: что нужно делать, чтобы наиболее полно выживать и чего не нужно делать, чтобы не приблизить собственное уничтожение.

Таким образом, излагая кому-нибудь чьюнибудь биографию, мы, так же как автор произведения, будем отбирать только те факты жизни героя нашего рассказа, которые проил- люстрируют собеседнику ту главную причину, которая показалась нам определяющей все его поступки и все перипетии его жизнедеятельности, которые и поставили его на грань выживания, погрузив, например, в одиночество, или, напротив, в излишне бурную деятельность. А чтобы подтвердить эту идею мы будем излагать факты биографии нашего героя. Но при этом пренебрежем множеством подробностей, отбросим все то, что не иллюстрирует нашу идею, то есть совершим определенный отбор и группировку бактов, сосредоточив наш рассказ лишь на связи между причиной и следствием. Этим самым мы выявим личный опыт выживания героя рассказа и, таким образом, транслируя собеседнику этот самый опыт выживания, предоставим ему самому решить - актуален ли этот опыт для него или он может его отбросить. Иначе говоря, рассказчик (автор) всегда каким-то образом «интерпретирует» жизнь своего героя в соответствии с той идеей, которая покажется ему главной причиной происходивших с героем событий. Тогда получается, чтоинтерпретацией мъ можем назвать трансляцию собеседнику (читателю, слуиателю, зрителю) определенного жизненного опыта посредством группировки определенных бактов (сюжет) для передачи определенной идеи (причины сюжета) посредством действия, т.е. последовательного разворачивания перед глазами зрителя цепочки причин, толкающих развитие сюжета. Тогда произведение искусства есть материальный объект (книга, фильм, спектакль, партитура, изваяние, картина, балет и т. д.), визуализирующий, делающий воспринимаемым невидимую, но существующую связь между причиной (идей) и следствием (фактами, событиями). Это определение равным образом будет касаться как исходного материала - драматургической основы спектакля. Так и самого спектакля, как продукта деятельности режиссера.

Поскольку трансляция опыта через произведение искусства происходит не через прямое нравоучение, выраженное в ряде формул и понятий, а в живом рассказе (образе), с узнаваемыми фактами и подробностями, то слушающий (смотрящий спектакль) такой рассказ имеет возможность воспринимать опыт не только умом (как научную формулу или нравоучение), но и чувствами, переживая и со-переживая герою рассказа (то есть мыс- 
ленно проживая его опыт). Так происходит то, что по меткому выражению C.M. Эйзенштейна заставляет его «...проделать тот же созидательный путь, которым прошел автор, создавая образ. Зритель не только видит изобразимые элементы произведения, но он и переживает динамический процесс возникновения и становления образа так, как переживал его автор. Это и есть, видимо, наибольшая возможная степень приближения к тому, чтобы зрительно передать во всей полноте ощущения и замысел автора, передать с «той силой физической ощутимости», с какой они стояли перед автором в минуты творческой работы и творческого видения.» [18, с. 156]

При этом принципиально важно то, что зритель становится не точкой приложения самовыражения автора, а соучастником, по сути - равноправным «со-творцом»: «зритель втягивается в такой творческий акт, в котором его индивидуальность не только не порабощается индивидуальностью автора, но раскрывается до конца в слиянии с авторским смыслом <...> Действительно, каждый зритель в соответствии со своей индивидуальностью, посвоему, из своего опыта, из недр своей фантазии, из ткани своих ассоциаций, из предпосылок своего характера, нрава и социальной принадлежности творит образ по этим точно направляющим изображениям, подсказаннъцм ему автором, непреклонно ведущим его к познанию и переживанию темы. Это тот же образ, что задуман и создан автором, но этот образ одновременно создан и собственным творческим актом зрителя» [18, с. 157].

Из всего вышесказанного отчетливо видно, что идея (как причина происходящих событий биографии), как критерий отбора событий, всегда заложена в самом ходе жизни, надо только уметь ее увидеть. И автор, выделяя какой-то кусок жизни, в соответствищ с видящейся ему в нем идеей отбираem uз этой жизюи определенные факты и события - причем, только те, которые наиболее ярко будут раскрывать увиденжую им идею, пренебрегая огромным количеством других фактов и подробностей, которые будут отвлекать восприятие читающего от раскрытия этой идеи. Так происходит «сжатие во времени» реальной жизни до жизни литературной, сценической, живописной, музыкальной и т. д., то есть так автором создается произведение искусства.

Таким образом, видно, что именно идея (причина сюжета - цепочки событий в жиз- ни персонажа) становится организующим произведение искусства фактором, определяющим в нем действие (развитие причин) и сюжет преемственность фактов). И сам сюжет в художественном произведении - это в соответствии с идеей определенным образом отобранные и сгруппированные факты. И не просто хаотично собранные в соответствии с их эффектностью («аттракционностью»), а тщательно подобранные - только те и только так сгруппированные, чтобы точно раскрывалась идея (причина) этих событий. Наличие осознанной идеи есть третье и важнейшее отличие произведения искусства от жизни, делающее произведение искусства именно искусством, а не жизненной копией. И об этом тоже писал C.M. Эйзенштейн «Следовало обратиться к тому основному, что в равной степени определяет как «внутрикадровое» содержание, так и композиционное сопоставление этих отдельных содержаний между собой, то есть к содержанию целого, общего, объединяющего<...>Следовало больше заняться вопросом самой природы этого объединяющего начала. Того именно начала, которое для каждой вещи в равной мере родит как содержание кадра, так и то содержание, которое раскрывается через то или иное сопоставление этих кадров.<...> Следовало бы обратиться к случаям, когда куски не только не безотносительны друг к другу, но когда само конечное, общее, цеелое не только предусмотрено, оно самое предопределяет как элементы, так и условия их сопоставления [18, с. 157].

Крайне важно для раскрытия нашей темы отметить, что другой рассказчик, излагая ту же самую биографию и те же самые события (цепочку фактов) может совершенно иначе выявить совершенно иные причины тех же событий. То есть по своему интерпретировать эти события (сюжет). Определяющим в этом процессе будет мировоззрение автора, которое у двух людей никогда не бывает одинаковым. Тогда он расскажет о том же герое совершенно иначе, соответственно и отбирая другие факты и группируя их принципиально иначе, так, чтобы они доказывали им лично найденную другую идею (причину собъเmuй) этой жизни.

Из этого хорошо видно, что автор пьесы или партитуры является первым интерпретатором жсизи и делает это посредством ограничения во времени и определенным отбором фактов в соответствии с определенной идеей. 
Тогда задача постановщика спектакля, как интерпретатора второго уровня $(\mathrm{OH}$ ведь интерпретирует не жизнь, а пьесу), прежде всего, понять, какой идеей (каким критерием отбора) руководствовался автор и зачем для сюжета он отобрал именно эти факты и события, пренебрегая огромным количеством других подробностей жизни своего персонажа или группы персонажей. Если этого не делать, то становится не нужным само произведение, как исходный материал для постановки и без него вполне можно обойтись.

Каким же образом постановщик способен выявить эту идею, этот критерий, которым руководствовался автор?

Мы уже выяснили, что в произведение искусства входят не все подряд факты естественного, жизненного хода событий, а только те, которые строго отобраны и определенным образом «смонтированы» в соответствии с каким-то критерием. Таким образом, мы получаем два мощных признака, точно демонстрирующих постановщику, что на самом деле имел в виду автор произведения. Однако, необходимо учитывать еще два фактора, о которых тоже много и подробно пишет С.М. Эйзенштейн. Это сам факт (его качество и общее их количество), который был избран автором и порядок его «сцепления» с другими фактами в сюжете.

Рассмотрим, что же такое факт, который должен войти в сюжет произведения. Какие к нему должны быть применены критерии, чтобы он мог встать в цепочку сюжета именно этого произведения? С.М. Эйзенштейн так же называет его главный признак: «Мало увидеть, нужно, чтобы с изображением что-то произошло, чтобы с ним что-то было проделано...» [18, с. 157]. Иначе говоря, просто скопированный из жизни, необработанный факт, «сырец» не может стать аргументом, подтверждающим идею автора в художественном произведении.

Но что должно быть проделано? Что превращает обычный жизненный факт в тот самый аттракцион, о котором пишет великий режиссер? И почему вообще сам факт, само же событие, вырванное из естественного хода жизни героя должно стать по меткому высказыванию С.М. Эйзенштейна своеобразным «аттракционом»?

Давая определение «аттракциону», С.М. Эйзенштейн так же подробно перечисляет его главные признаки: «Аттракцион в формальном плане я устанавливаю как са- мостоятельный и первичный элемент конструкции спектакля - молекулярную (то есть составную) единицу действенности театра и театра вообще» $[17$, с. 270]. При том сам аттракцион должен, по мысли С.Н. Эзенштейна, обладать рядом специфически-важных характеристик, весьма точно выделенных и охарактеризованных режиссером: «Аттракцион (в разрезе театра) - всякий агрессивный момент театра, то есть всякий элемент его, подвергающий зрителя чувственному или психологическому воздействию, опытно выверенному u математически рассчитанному на определенные эмоциональные потрясения воспринимающего[разрядка моя-A.Ч.], в свою очередь в совокупности единственно обусловливающие возможность восприятия идейной стороны демонстрируемого - конечного идеологического вывода. (Путь познавания - «через живую игру страстей» - специфический для театра.)» $[17$, с. 269] То есть реально происходившее событие, имевший в жизни персонажа место факт, превращенный в момент сценического действия (аттракцион) должен быть «обработан» идеей (в нем эту идею надо увидеть и усилить, т.е. реальный факт подвергается определенному искажению авторской фантазией) и потому начать обладать смъсловой самостоятельностъю. То есть сцена, написанная автором, не может быть случайной в структуре пьесы (партитуры) - она сама в своей основе несет не только факт, но и (как в капле воды - море) отражает суть идеи. Чтобы так происходило, чаще всего автор, беря за основу реальные события, иуть-гуть их искажает, сгущая краски или напротив, пренебрегая чем-то в угоду значимости какой-то иной детали, которая более явно подскажет зрителю, зачем именно эта сцена (этот факт) поставлен в ряд событий пьесы (партитуры). Акцентирование идеи, фантазийное искажение и превращает жизненное событие в аттракцион, делая его выпуклым, ярким, эффектным, парадоксальным, неожиданным, цепляющим зрительское внимание, поражающим своей неожиданной значимостью, поскольку «в этом случае каждый монтажный кусок существует уже не как нечто безотносительное, а являет собой некое частное изображение единой общей темы, которая в равной мере пронизывает все эти куски. Сопоставление подобных частных деталей в определенном строе монтажа вызывает к 
жизни, заставляет возникнуть в восприятии то общее, что породило каждое отдельное и связывает их между собой в целлее, а именно - в тот обобщенный образ, в котором автор, а за ним и зритель переживают данную тему» [18, с. 157]. При этом С.М. Эйзенштейн особо указывает, что при таком подходе «как кадры, так и их сопоставление оказываются в правильном взаимоотношении. Мало того, сама природа монтажа не только не отрывается от принципов реалистического письма фильма, но действует как одно из наиболее последовательных и закономерных средств реалистического раскрытия содержания». [18, с. 157].

Допустив искажение на уровне одного факта, преображая его путем фантазии для того, чтобы он в сконцентрированном виде отражал суть целого, автор должен озаботиться теперь и тем, каким способом эта цепочка отобранных из жизни и преображенных в аттракцион фактов должна «сцепиться» между собой в структуре художественного произведения. И тут в действие вступает правило строгого коррелирования одного эпизода-аттракциона с другими выбранными автором эпизодами.

Зачем это нужно? Чтобы не порвался сюжет? Однако, на примере многочисленных произведений искусства мы видим, что зачастую сюжет долгое время бывает не понятен публике, поскольку события следуют не в хронологическом например, порядке, или значительно разорваны во времени. Бывает, что автор перебрасывает внимание читателя (зрителя) с на фактов жизни одного персонажа на факты жизни другого и читатель (зритель) долгое время не может установить внешней, сюжетной связи между этими частями пьесы или романа т. д. Не говоря уж о том, что по отношению к исходным жизненным событиям сюжет художественного произведения бывает настолько искажен кажущейся самоцельной фантазией автора, что сами события и прототипы персонажей становятся и вовсе не узнаваемы ${ }^{7}$.

В чем же принцип коррелирования «аттракционов» между собой, если он не основан на простом сюжетном движении событий? C.M. Эйзенштейн поясняет: на соотношении смыслов, оттенков идеи каждого отдельного эпизода. Каждый факт, преображенный фантазией автора (трактованный идеей) должен располагаться относительно другого так, чтобы максимально эту идею выявлять: «кусок Л, взятый из элементов раз- вертываемой темы, и кусок $B$, взятый оттуда же, в сопоставлении рождают тот образ, в котором наиболее ярко воплощено содержание темы. Выраженное в императивной форме, более точно и более оперативно, это положение прозвучит так: изображение $A$ u изображение $B$ должны быть так выбраны из всех возможных черт внутри развиваемой темы, должны быть так выисканы, чтобы сопоставление их - именно их, а не других элементов - вызывало в восприятии и чувствах зрителя наиболее исчерпывающе полный образ самой темы. [18, с. 157].

Иначе говоря, эпизоды в пьесе или романе следуют не за естественным ходом развития сюжета, но за логикой развития идеи (внутренних причин происходящего). Поэтому сюжет может быть хронологически не только сломан, но и допускать, чтобы события, которые в реальной жизни происходили позже, могли бы появиться перед взором воспринимающего раньше. Кроме того, подчас, в произведение искусства входят события не из одной реальной человеческой жизни, а из нескольких сразу, однако приписываются они ходу сюжета (жизни) одного сочиненного персонажа. Поэтому сюжет является лишь средством раскрытия идеи.

Но не только расстановка эпизодов в определенном порядке, но и сам принцип соединения эпизодов (собственно сам монтаж) тоже есть смыслообразующее начало. При этом важно понимать, что монтируются не столько стыки сюжета, сколько стыки развития действия (идеи): «Верным оставался и на сегодня остается факт, что сопоставление двух монтажных кусков больше похоже не на сумму их, а на произведение. На произведение - в отличие от суммы - оно походит тем, что результат сопоставления качественно (измерением, если хотите, степенью) всегда отличается от каждого слагающего элемента, взятого в отдельности» [18, с. 157]. Так происходит потому, что человеческое мышление имеет определенные закономерности, в частности - мыслительную способность к обобщению: «два каких-либо куска, поставленные рядом, неминуемо соединяются в новое представление, возникающее из этого сопоставления как новое качество. Это отнюдь не сугубо кинематографическое обстоятельство, а явление, встречающееся неизбежно во всех случаях, когда мы имеем дело с сопоставлением двух фактов, явлений, предметов. Мы привыкли почти ав- 
томатически делать совершенно определенный трафаретный вывод - обобщение, если перед нами поставить рядом те или иные отдельные объекты.<...> Мы автоматически сопоставляем оба элемента и сводим их воедино». [18, с. 156].Пренебрегающие (а подчас и не подозревающие об этом качестве мышления человека) авторы и режиссеры мало отдают себе отчет в том нелепом положении, в котором они оказываются, когда «городят» в пьесе или на сцене ряд «эффектных ходов». Не определенные идеей, смыслом, сами по себе самоцельно броские, яркие по форме и поэтому «цепляющие» зрительское внимание, они в сочетании, подчас выдают такую бессмыслицу, которая делает авторское «высказывание» (произведение) полностью не воспринимаемым. Еще забавнее, когда автор пьесы или спектакля с обидой пытается восстановить справедливость, доказывая, что читатель или постановщик или критик существенно исказил его произведение. Но при этом даже не подозревает, что виноват в этом он сам. Такой автор или постановщик вряд ли отдает себе отчет в том, что на самом деле он написал или поставил, поскольку он изначально пренебрег знанием об этом свойстве человеческого мышления - обобщать. Не ведая, что творит, такой «деятель искусства» с пеной у рта может доказывать то, что он «имел в виду совершенно другое», однако его непрофессионализм делает свое дело без него: соединенные между собой по принципу эффекта, броскости, а не по принципу смысла «кадры»-эпизоды начинают помимо авторской воли жить своей жизнью: продуцировать совершенно противоположные авторскому замыслу, самостоятельные значения в мозгу у зрителя.

Между тем, сам порядок и принцип сцепления эпизодов так же есть средство для выражения авторской идеи, раскрывая ее для воспринимающего очередной гранью: «Задача состоит в том, чтобы, творчески разложив тему в определяющие изображения, затем эти изображения в их сочетании заставить вызывать к жизни исходный образ темы. Процесс возникновения этого образа у воспринимающего неразрывен с переживанием темы его содержания. Совершенно так же неразрывен с таким же острым переживанием и труд режиссера, когда он пишет свой монтажный лист. Ибо только подобный путь единственно способен подсказать ему решающие изображения, через которые действительно и засверкает в восприятии цельность образа темы» $[18$, с. 156]. То есть произведение искусства в конечном итоге представляет собой некую пирамиду, где в подошве ее расположены кажущиеся бессмысленными и бессистемными факты сюжета, а в вершине - исходная идея, которая определяет само существование этих фактов в сюжете.

Таким образом, по способу сжатия времени, по критерию и отбору определенных эпизодов, их качеству и способу их сцепления между собой (монтажу) режиссер вполне способен восстановить для себя первъцй уровенъ интерпретации жизни - авторскую идею. Он получает, таким образом, по меткому выражению С.M. Эйзеншетйна, некий шифр: «Сценарий - это шифр. Шифр, передаваемый одним темпераментом - другому» [19, с. 298]. Получив этот шифр и озаботившись тем, чтобы его дешифровать, режиссер волен как полностью согласиться с авторской интерпретацией явления действительности (с причинами, которые кажутся автору наиболее реальными для происходящих событий), так и не согласиться. В этом случае режиссер выбирает, например, Горького, с которым совпадает в видении причин реальности и не выбирает, скажем, Мопассана, чье видение причин сюжета ему не близко даже, если нравится сам сюжет.

Однако, крайне актуален вопрос, можно ли причины сюжета (идеи), сходные с мировидением Горького встраивать в Мопассана (или наоборот) только потому, что режиссеру нравится сюжет? И насколько могут расходиться видения причин сюжета избранного к постановке произведения у автора и режиссера? Могут ли они быть совершенно разными? Может ли режиссер взять сюжет автора и «встроить» в него свои причины (свою идею)? Насколько причины сюжета Мопассана или Горького могут быть искажены режиссероминтерпретатором?

Нет, не может, потому что сама структура сюжета принципиально «заточена» под определенную идею и ее, и только ее выражает. Профессия режиссера - это профессия вторичного уровня интерпретации по отношению к готовой (данной автором) $\boldsymbol{x y \partial о ж е - ~}$ ственной реальности, которая отличается от аморфного хода жизни, прежде всего тем, что в ней ужсе найдена идея, и она стала организующим это художественное произведение принципом. При кажущемся сходстве процессов интерпретации -точно так 
же, как автор не создает человеческую жизнь, а интерпретирует ее в своем произведении, преображая ее в новую художественную, искусственную реальность, режиссер, тем не менее, является лишь интерпретатором, но уже созданной художественной реальности. Разница в положениях по отношению к исходной жизненной реальности и в приемах: один (первый уровень) делает это литературными средствами, второй (второй уровень) - сценическими. То есть отношение к современной ему реальности режиссер отражает и выражает посредством уже готовой искусственной реальности - пьесы. И это принципиально важно понимать.

В остальном процесс создания произведения искусства у автора и режиссера вполне схож. Как автор причины происходящих событий «вычитывает» в жизни и посредством своего литературного мастерства лишь выявляет их для читателя, так и режиссер - вычитывает их, но в пьесе и посредством своего постановочного языка визуализирует их для зрителя. То есть пьеса, партитура для режиссера становится неким исходным моментом жизни, который нуждается в интерпретации, как для автора - исходная жизнь. Но, повторимся, поскольку это важно - в интерпретации второго уровня, а не первого, как у автора $^{8}$. С той разницей, что автор переакценитрует (интерпретирует) свободный, аморфный ход жизни и потому волен сам отбирать необходимые ему для этой интерпретации жизненные эпизоды, а вот у режиссера они уже жестко даны. Автор берет эпизоды из жизни, режиссер - из пьесы, автор искажает эпизод реальности, режиссер имеет его уже искаженный авторской идеей. Наконец, автор волен сам создать структуру своего произведения, отбирая и организуя эти эпизоды в определенном порядке, режиссер же ужсе uмeеm эту структуру и может лишь усилить или приглушить ее связи.

Тогда, поскольку режиссер интерпретирует чужую художественную реальность и этим зажат в весьма «жесткие» рамки - в чем же свобода творчества режиссера? Что должно происходить с режиссером, когда он касается «исходного момента жизни» в виде уже интерпретированной автором и созданной заново, искусственно - художественной реальности - пьесы или партитуры? И каковы его права по отношению к этой реальности? Может ли он полностью сменить причины (идеи) происходящего в пьесе сюжета?
Нет, не может. Он может только согласиться (совпасть) с теми причинами (идеей), которую всем строем своего произведения выявил автор. То есть увидеть сюжет и его причины почтu глазами автора. Почти, потому что они все равно не увидят ее одинаково, скажутся расхождения в менталитете, времени и жизненном опыте. Режиссер может и не согласиться автором, но в этом случае, он не принимает пьесу к постановке. Иначе говоря, критерием выбора драматургического материала к постановке должен являться не сюжет, позволяющий построить ряд самоцельных эффектов, а идея произведения.

Но получается, что согласившись с автором, режиссер может только проиллюстрировать авторскую идею? Где же тогда самостоятельность видения режиссера? И имеет ли он на это право?

Да имеет. Но не на смену идеи, а на переакценитровку способов ее изложения и визуализации. Но не на полную переорганизацию авторской структуры художественного произведения. Сопоставляя сюжет пьесы - некую цепочку фактов, данную автором, подчас далеко отстоящих от режиссера во времени - с сюжетами современной ему жизни, режиссёр вполне способен установить некое родство u похожесть причин (идей), выявленных автором для своего сюжета и установленных режиссером для похожих событий современности. Родство и похожесть, но не кардинальную разницу. Об этом очень точно пишет Г.А. Товстоногов: «Попробуйте, например, переодеть в современные костюмы героев комедии А.Н. Островского «На всякого мудреца довольно простоты». Ничего не получится. Пьеса прозвучит фальшиво, глупо и бессмысленно. Значит ли это, что в нашей жизни нет уже ловких карьеристов, суеверных старух, выживших из ума приверженцев старины и т.п.? К сожалению, такие еще попадаются. Но современный Глумов будет куда более осторожным, ибо по нынешним временам разоблачение ему грозит куда большими неприятностями, чем Глумову Островского, без которого Мамаевы и Крутицкие обойтись не могут. Современный Крутицкий не может иметь сколько-нибудь значительную власть и нынешнему Глумову он вряд ли сможет оказать протекцию» [14, с. 34].

Тогда, проанализировав по вышеуказанным критериям авторский замысел и выделив для себя все те акценты, которые рас- 
ставил автор, чтобы сделать видимой свою идею, режиссер в своей постановке волен лишь приглуишть одни акценты, и усилuть другие как внутри отдельного «кадра»эпизода пьесы, так и в структуре (монтаже) целого произведения. И сделать это своими средствами - подбором актеров, решением пространства, светом и прочими атрибутами его профессии. То есть перевести идею автора на свой язык.

И именно этой переакценировкой $\boldsymbol{u}$ переводом в другие средства выражения, за счет которых и осуществляется эта переакцентировка - усиление одних авторских черт и приглушение других режиссер и добивается нового прочтения, т.е. более яркой, более понятной для современников визуализации авторских причин происходивших событий. Иначе говоря, современность интерпретации - это усиление режиссером идеи автора и в повороте ее за счет сценических средств под другим углом зрения. Усиление это одинаковыми сценическими средствами просто не возможно - каждый из режиссеров подбирать средства выражения идеи автора будет собственные, а выбор их у театра, как известно, безграничен.

В этом суть процесса интерпретации режиссером данной ему как исходная жизненная реальность пьесы. «Соавтор своими средствами запечатлевает в сценарии ритм своей концепции, - пишет С.М. Эйзенштен. - Приходит режиссер и переводит ритм этой концепции на свой язык <...>, находит кинематографический эквивалент литературному высказыванию. В этом корень дела. А вовсе не в переложении в цепь картин, анекдотической цепи событий сценария» [19, с.298]

Иными словами, автор по отношению к жизни более свободен, нежели режиссер, ограниченный видением автора. Не более того.

Тогда режиссёрской интерпретацией драматургического произведения можно назвать интерпретацию второго уровня. Режиссер транслирует зрителю определенный авторский жизненный опыт, который похож или совпал с собственным. Делает он это посредством серуппированных автором определенных фактов (сюжет) для передачи определенной автором идеи (причины сюжета) посредством действия, т.е. сценическими средствами последовательного разворачивающихся перед глазами зрителя визуализированных причин, толкающих развитие сюжета.

Подобным образом различая функции деятельности режиссёра и автора, мы получаем не только четкий механизм анализа исходного драматургического материала для дальнейшего его сценического воплощения, но и жесткий критерий профессионализма работы режиссера.

\section{Библиография:}

1. Захава Б.Е. Мастерство Актера и Режиссера. М.: Искусство, 1969. 319 с.

2. Кнебель М.О. О действенном анализе пьесы и роли. М.: Искусство, 1959. 70 с.

3. Кнебель М.О. Школа режиссуры Немировича-Данченко. М.: Искусство, 1966. 167 с.

4. Крымова Н.А. Станиславский - режиссер. М.: Искусство, 1971. 170 с.

5. Молочевская И.Б. Режиссерская школа Товстоногова. СПб.: СПб ГАТИ, 2003. 156 с.

6. Норенко В.В. Режиссерский замысел в теории режиссуры. Л.: Высш. Профсоюзн. Школа культ, 1984. 68 с.

7. Попов А.Д. Спектакль и режиссер. М.: ВТО. 1972. 100 с.

8. Попов П.Г. Режиссура. О методе. М.: ВХТЦ, 2003. 64 с.

9. Ремез О.Я. Мастерство режиссера. Пространство и время спектакля. М.: Просвещение, 1983. 143 с.

10. Слесарь Е.А. режиссер-драматург: модели их взаимоотношений в зарубежном и отечественном театре конца ХІХ-ХХ веков: Автореф. дисс. ... канд. М.: Искусство, 2006. 26 с.

11. Сулимов М.В. Режиссер наедине с пьесой // Посвящение в режиссуру. СПб.: Издат. Дом СПб. гос. ун-та, 2004. C. 459-550

12. Станиславский К.С. Театральное наследство. Т. 1. Материалы. Письма. Исследования. М.: Из-во Академии Наук СССР, 1955. 698 с.

13. Тазетдинова Р.Р. Философско-культурологический аспект режиссерского анализа художественного текста. Автореф. дисс. ... канд. философских наук. Казань, 2008. 178 с.

14. Товстоногов Г.А. О профессии режиссера. М.: ВТО, 1967. 358 с.

15. Товстоногов Г.А. Беседы с коллегами. Попытка осмысления режиссерского опыта. С, СТД РСФСР, 1988.528 с. 
16. Эйзенштейн С.М. Монтаж аттракционов // Избранные произведения: В 6 т. М.: Искусство, 1964. 566 с

17. Эйзенштейн С.М. Монтаж // Избранные произведения: В 6 т. М.: Искусство, 1964. Т. 2. 566 с

18. Эйзенштейн С.М. О форме сценария // Избранные произведения: В 6 т. М.: Искусство, 1964. Т. 2. 566 с

19. Эфрос А.В. Профессия режиссер. В 4 кн. Кн. 2. М.: Парнас, 1993. 368 с.

20. Юзовский Ю. О театре и драме. В 2-х т. Т. 1. М,: Искусство, 1982. 487 с.

\section{References (transliterated):}

1. Zakhava B.E. Masterstvo Aktera i Rezhissera. M.: Iskusstvo, 1969. $319 \mathrm{s.}$

2. Knebel' M.O. O deistvennom analize p'esy i roli. M.: Iskusstvo, 1959. $70 \mathrm{s.}$

3. Knebel' M.O. Shkola rezhissury Nemirovicha-Danchenko. M.: Iskusstvo, 1966. 167 s.

4. Krymova N.A. Stanislavskii - rezhisser. M.: Iskusstvo, 1971. $170 \mathrm{s.}$

5. Molochevskaya I.B. Rezhisserskaya shkola Tovstonogova. SPb.: SPb GATI, 2003. 156 s.

6. Norenko V.V. Rezhisserskii zamysel v teorii rezhissury. L.: Vyssh. Profsoyuzn. Shkola kul't, 1984. 68 s.

7. Popov A.D. Spektakl' i rezhisser. M.: VTO. 1972. $100 \mathrm{s.}$

8. Popov P.G. Rezhissura. O metode. M.: VKhTTs, 2003. 64 s.

9. Remez O.Ya. Masterstvo rezhissera. Prostranstvo i vremya spektaklya. M.: Prosveshchenie, 1983. 143 s.

10. Slesar' E.A. rezhisser-dramaturg: modeli ikh vzaimootnoshenii v zarubezhnom i otechestvennom teatre kontsa XIX-XX vekov: Avtoref. diss. ... kand. M.: Iskusstvo, 2006. 26 s.

11. Sulimov M.V. Rezhisser naedine s p'esoi // Posvyashchenie v rezhissuru. SPb.: Izdat. Dom SPb. gos. un-ta, 2004. S. 459-550

12. Stanislavskii K.S. Teatral'noe nasledstvo. T. 1. Materialy. Pis'ma. Issledovaniya. M.: Iz-vo Akademii Nauk SSSR, 1955. $698 \mathrm{~s}$.

13. Tazetdinova R.R. Filosofsko-kul'turologicheskii aspekt rezhisserskogo analiza khudozhestvennogo teksta. Avtoref. diss. ... kand. filosofskikh nauk. Kazan', 2008. $178 \mathrm{s.}$

14. Tovstonogov G.A. O professii rezhissera. M.: VTO, 1967. 358 s.

15. Tovstonogov G.A. Besedy s kollegami. Popytka osmysleniya rezhisserskogo opyta. S, STD RSFSR, 1988.528 s.

16. Eizenshtein S.M. Montazh attraktsionov // Izbrannye proizvedeniya: V 6 t. M.: Iskusstvo, 1964. $566 \mathrm{~s}$

17. Eizenshtein S.M. Montazh // Izbrannye proizvedeniya: V 6 t. M.: Iskusstvo, 1964. T. 2. $566 \mathrm{~s}$

18. Eizenshtein S.M. O forme stsenariya // Izbrannye proizvedeniya: V 6 t. M.: Iskusstvo, 1964. T. 2. 566 s

19. Efros A.V. Professiya rezhisser. V 4 kn. Kn. 2. M.: Parnas, 1993. 368 s.

20. Yuzovskii Yu. O teatre i drame. V 2-kh t. T. 1. M,: Iskusstvo, 1982. 487 s. 